\title{
POTENSI TUMBUHAN BAWAH PADA TEGAKAN HUTAN TANAMAN Acacia crassicarpa A. Cunn. ex Benth SEBAGAI PAKAN GAJAH DAN PENYIMPAN KARBON DI KABUPATEN OGAN KOMERING ILIR
}

\author{
(The Potential of Understorey in Acacia crassicarpa A. Cunn. ex Benth Plantation for \\ Elephant Feed and Carbon Storage in Ogan Komering Ilir Regency)

\section{R. Garsetiasih, Anita Rianti dan/and N.M. Heriyanto} \\ Pusat Penelitian dan Pengembangan Hutan \\ Jl. Gunung Batu No. 5, Kotak Pos 165 Bogor 16118, Jawa Barat, Indonesia \\ Telp. +62-251-8633234; Fax. +62-251-8638111
}

Tanggal diterima: 5 Januari 2018; Tanggal direvisi: 28 Agustus 2018; Tanggal disetujui: 29 Oktober 2018

\begin{abstract}
Understorey in a forest area can be utilized as herbivorous animal feed, as well as carbon storage. In Ogan Komering Ilir (OKI) Regency, the understorey is utilized by elephant as feed habitat. The study aimed to determine the diversity, productivity and potential for carbon content of understorey in A. Crassicarpa plantation in OKI Regency. The method used for collection of understorey data was square plot method with $1 x 1 m$ size, where the first plot was determined randomly and followed by the subsequent plots systematically. The results found out 8 types of understorey species with important index values in sequence were Nephrolepis biserrata $(S w)$ Schott. 66.90\%; Melastoma malabathricum L. 44.14\% and Stenochlaena palustris (Burm. F.) Bedd. $36.18 \%$. The species of feed that most eaten by the elephants were Nephrolepis biserrata (Sw.) Schott., Cyperus kyllinga Endl. and Stenochlaena palustris (Burm.f.) Bedd. The domination of understorey in the stand of Germplasm Conservation Area (KPPN) (0,1611) was greater compared to those in block $A(0,1124)$ and block E (0,1512). The total biomass of the understorey in Block A (3 year old $\underline{\mathrm{A}}$. Crassicarpa stand), E Block (3,3 year old A. Crassicarpa stand), and KPPN were $561,8 \mathrm{~kg} / \mathrm{ha} ; 371,48 \mathrm{~kg} / \mathrm{ha}$; and $383,84 \mathrm{~kg} / \mathrm{ha}$, respectively. Carrying capacity of the understorey as feed for elephants during the dry season in block A was for 10,54 elephants; block E was for 2,10 elephants and KPPN was for 79,37 elephants. Therefore, in order to meet the requirement of elephant feed and minimize elephant interference to plantation, the quality of KPPN needs to be improved.
\end{abstract}

Key word : Acacia crassicarpa, carbon, diversity, productivity, undergrowth

\begin{abstract}
ABSTRAK
Tumbuhan bawah hutan selain berfungsi sebagai pakan satwa herbivora juga dapat menyimpan karbon. Tumbuhan bawah pada tegakan Acacia crassicarpa di Kabupaten Ogan Komering Ilir juga dimanfaatkan oleh gajah sebagai habitat pakan. Tujuan penelitian adalah untuk mengetahui keanekaragaman dan produktivitas tumbuhan bawah serta potensi kandungan karbonnya. Pengumpulan data tumbuhan bawah menggunakan metode plot bujur sangkar berukuran $1 \mathrm{~m} \mathrm{x} 1 \mathrm{~m}$, penentuan plot pertama dilakukan secara acak dan selanjutnya secara sistematik. Hasil penelitian dijumpai delapan jenis tumbuhan bawah dengan nilai indeks penting secara berurutan yaitu paku harupat (Nephrolepis biserrata) sebesar 66,90\%, harendong (Melastoma malabathricum) 44,14\% dan jenis paku udang (Stenochlaena palustris) 36,18\%. Penguasaan jenis tumbuhan bawah pada tegakan Kawasan Pelestarian Plasma Nutfah (KPPN) lebih besar $(0,1611)$ dibandingkan pada tegakan di blok A dan blok E (0,1124 dan 0,1512). Biomassa tumbuhan bawah di blok A (tegakan A. crassicarpa 3 tahun), blok E (tegakan A. crassicarpa 3,3 tahun) dan Kawasan Pelestarian Plasma Nutfah (KPPN) berturut-turut adalah 561,8 kg/ha; $371,48 \mathrm{~kg} / \mathrm{ha}$; dan 383,84 kg/ha. Daya dukung tumbuhan bawah sebagai pakan gajah pada saat musim kemarau di blok A adalah 10,54 gajah; blok E sebesar 2,10 ekor gajah dan areal KPPN sebesar 79,37 gajah. Untuk memenuhi kebutuhan pakan gajah serta meminimalisir gangguan gajah terhadap hutan tanaman perlu peningkatan kualitas KPPN.
\end{abstract}

Kata kunci : Acacia crassicarpa, karbon, keanekaragaman, produktivitas, tumbuhan bawah 


\section{PENDAHULUAN}

Keberadaan tumbuhan bawah khususnya di lantai hutan dapat berfungsi sebagai penahan pukulan/limpahan air hujan dan aliran permukaan, sehingga meminimalkan bahaya erosi serta sebagai hijauan pakan satwa herbivora. Tumbuhan bawah juga sering dijadikan sebagai indikator kesuburan tanah dan penghasil serasah dalam meningkatkan kesuburan tanah (Soerianegara \& Indrawan, 2008). Selain fungsi ekologi, beberapa jenis tumbuhan bawah telah diidentifikasi sebagai tumbuhan yang dapat dimanfaatkan sebagai bahan pangan (manusia, ternak, atau satwa herbivora), tumbuhan obat, dan sebagai sumber energi alternatif (Abdiyani, 2008). Tumbuhan bawah berfungsi sebagai penyedia hijauan pakan satwa herbivora yang penyebarannya meliputi hutan alam, hutan tanaman industri (HTI), dan hutan konservasi (Hidayat \& Hardiansyah, 2012). Namun, tumbuhan bawah juga dapat berdampak negatif sebagai gulma yang invasif dan menghambat pertumbuhan permudaan pohon khususnya pada tanaman monokultur yang dibudidayakan masyarakat (Suprihatno, Hamidy, \& Amin, 2012).

Dalam suatu ekosistem hutan, masyarakat tumbuh-tumbuhan berhubungan erat antara satu sama lain dengan lingkungannya. Hubungan ini ditunjukkan dengan adanya keanekaragaman dalam jumlah masing-masing jenis tumbuhan dan terbentuknya struktur masyarakat tumbuh-tumbuhan tersebut. Terbentuknya pola keanekaragaman dan struktur jenis vegetasi hutan merupakan proses yang dinamis, erat hubungannya dengan kondisi lingkungan baik biotik maupun abiotik. Tumbuhan bawah adalah suatu tipe vegetasi dasar yang terdapat di bawah tegakan hutan kecuali permudaan pohon hutan, yang meliputi rerumputan, herba, dan semak belukar. Dalam stratifikasi hutan hujan tropika, tumbuhan bawah menempati stratum D yakni lapisan perdu, semak, dan lapisan tumbuhan penutup tanah pada stratum E (Soerianegara \& Indrawan, 2008).

Hutan tropika basah merupakan salah satu sumberdaya alam hayati yang memiliki peran penting dalam ekosistem, yaitu keanekaragaman hayatinya dan sebagai penyerap (rosot) karbondioksida $\left(\mathrm{CO}_{2}\right)$ dari udara. Menurut INCAS (2015) di Indonesia dengan emisi $\mathrm{CO}_{2}$ terbesar terjadi tahun 2006 sebesar 195 juta ton $\mathrm{CO}_{2}{ }^{-\mathrm{e}}$. dan terendah tahun 2010 dengan 74 juta ton $\mathrm{CO}_{2}{ }^{-\mathrm{e}}$. Hasil penelitian Purwanta (2010), menyatakan emisi karbondioksida dari tahun 2001-2006 sebesar 827.058 $\mathrm{CO}_{2}$ ekuivalen $\mathrm{Gg} /$ tahun yang berasal dari proses industri atau 6\% dari keseluruhan sektor yang dihitung. Untuk mengatasi masalah tersebut peran hutan sebagai penyerap $\mathrm{CO}_{2}$ harus dikelola dengan baik. Rosot karbondioksida berhubungan erat dengan biomassa tegakan, jumlah biomassa suatu daerah diperoleh dari produksi kepadatan biomassa dan jenis pohon (Bismark, Heriyanto, \& Iskandar, 2008; Onrizal, Ismail, Perbatakusuma, Sudjito, Suprijatna, \& Wijayanto, 2008; Siregar, \& Heriyanto, 2010; Dharmawan, \& Samsoedin, 2012;).

Penelitian pendugaan biomassa dan kandungan karbon di hutan tropis masih perlu dilakukan dan dibutuhkan karena potensi biomassa hutan yang besar dalam menyerap karbon. Hutan tropis mempunyai potensi yang besar dalam pengurangan kadar $\mathrm{CO}_{2}$ melalui konservasi dan manajemen kehutanan (Onrizal, \& Kusmana, 2009; Subiandono, Bismark, \& Heriyanto, 2013). Informasi mengenai biomassa dan produktivitas tumbuhan bawah dapat digunakan sebagai dasar dalam pengelolaan satwa liar khususnya aspek ketersediaan pakan satwa herbivora (Masy'ud, Kusuma, \& Rachmandani, 2008).

Dalam mekanisme pembangunan bersih, negara maju diharuskan mengurangi emisi karbondioksida $\left(\mathrm{CO}_{2}\right)$, adapun negara berkembang yang umum- 
nya terletak di daerah tropik diwajibkan mencegah kerusakan hutan yang bertujuan untuk mengurangi pemanasan global (Lugina, Ginoga, Wibowo, Bainnaura, \& Partiani, 2011). Pertumbuhan pohon di daerah tropik yang lebih cepat bila dibandingkan dengan negara yang beriklim sub tropik menyebabkan besarnya perhatian negara maju terhadap kelestarian hutan tropis karena berpotensi tinggi dalam menyerap emisi gas yang dapat menyebabkan perubahan iklim yang tidak diinginkan. Oleh karena itu, Indonesia yang mempunyai hutan tropis terbesar ketiga di dunia setelah Brazil dan Kenya perlu mempunyai data dasar hutan tropis dalam menyerap karbon. Data dasar akan sangat berguna apabila peraturan tentang perdagangan karbon dunia berhasil diratifikasi (Siregar, \& Heriyanto, 2010).

Penelitian ini bertujuan untuk mengetahui keanekaragaman dan potensi tumbuhan bawah sebagai pakan satwa herbivora serta potensi kandungan karbonnya pada tegakan Acacia crassicarpa A. Cunn. ex Benth. umur 3 tahun; 3,3 tahun; dan Kawasan Pelestarian Plasma Nutfah (KPPN) di kawasan Hutan Tanaman Industri (HTI). Kawasan hutan tersebut juga merupakan daerah jelajah gajah di Kabupaten Ogan Komering Ilir, Provinsi Sumatera Selatan. Hasil penelitian diharapkan dapat memberikan gambaran keanekaragaman tumbuhan bawah dan tingkat kemampuan tumbuhan bawah dalam menyerap dan mengurangi kadar karbondioksida di udara, serta produktivitasnya sebagai pakan herbivora khususnya gajah. Gajah merupakan satwa yang dilindungi, berdasarkan IUCN (International Union for Conservation of Nature and Natural Resources) Red list, masuk katagori Endangered dan Appendix I CITES (Convention on International Trade of Endangered Species Flora and Fauna), sehingga keberadaannya perlu dilestarikan. Penelitian ini diharapkan dapat dijadikan acuan dalam pengelolaan hutan tanaman industri A crassicarpa yang sekaligus dapat menjaga kelestarian lingkungan di dalamnya yang merupakan habitat satwa liar diantaranya gajah.

\section{METODOLOGI}

\section{A. Tempat dan Waktu Penelitian}

Penelitian dilakukan pada bulan Agustus 2017 sampai bulan November 2017 di HTI PT. Bumi Mekar Hijau, pada jenis tegakan A. crassicarpa umur 3 tahun, 3,3 tahun, dan KPPN. Ketiga lokasi ini dipilih karena merupakan daerah jelajah salah satu satwa herbivora yang statusnya dilindungi berdasarkan PP No. 7 Tahun 1999 dan IUCN yaitu gajah sumatera (Elephas maximus sumatranus). Secara administrasi pemerintahan lokasi ini termasuk dalam Desa Riding, Kecamatan Pangkalampam, Kabupaten Ogan Komering Ilir (OKI), Provinsi Sumatera Selatan. Secara administrasi kehutanan termasuk wilayah Dinas Kehutanan Wilayah Timur (Unit I), Wilayah Selatan (Unit II), dan Wilayah Utara (Unit III), Kabupaten Ogan Komering Ilir (OKI).

Lokasi penelitian merupakan bagian dari IUPHHK-HT (Ijin Usaha Pemanfaatan Hasil Hutan Kayu-Hutan Tanaman) PT. Bumi Mekar Hijau dari luas \pm 250.370 ha. Gambar peta lokasi penelitian ditunjukkan pada Gambar 1.

\section{Topografi, tanah dan iklim}

Lokasi penelitian berada di lahan gambut yang terletak pada ketinggian \pm 18 $\mathrm{m}$ di atas permukaan laut (dpl), topografi datar dengan lereng 0-8\%. Jenis tanah didominasi oleh Aluvial Hidromorf (Pusat Penelitian Tanah \& Agroklimat, 2013). Iklim di Kabupaten Ogan Komering Ilir tergolong dalam Tropik Basah dengan curah hujan rata-rata tahunan $>2.500$ $\mathrm{mm} /$ tahun dan jumlah hari hujan rata-rata $>116$ hari/tahun. Musim kemarau umumnya berkisar antara bulan Mei sampai 
Oktober, sedangkan musim penghujan berkisar antara bulan November sampai bulan April. Penyimpangan musim biasanya terjadi sekali dalam lima tahun, berupa musim kemarau yang lebih panjang dari musim penghujan, dengan rata-rata curah hujan lebih kurang 1.000 $\mathrm{mm} /$ tahun dengan rata-rata hari hujan 60 hari/tahun (BPS, 2016).

\section{B. Metode}

Untuk mengetahui komposisi vegetasi tumbuhan dan persen penutupan di bawah tegakan $A$. crassicarpa dan hutan alam (KPPN) dilakukan analisis vegetasi dengan petak contoh berukuran $1 \mathrm{~m} \mathrm{x} 1 \mathrm{~m}$. Penentuan plot pertama dilakukan secara acak dan satuan contoh selanjutnya dilakukan secara sistematik (Baccaro et al., 2015). Sampel plot yang digunakan sebanyak 15 plot per tegakan, jarak antara plot $50 \mathrm{~m}$. Jumlah plot tersebut dianggap cukup karena tegakannya homogen. Untuk mengetahui kandungan karbon dan potensi tumbuhan bawah sebagai pakan satwa gajah pada tumbuhan bawah dilakukan pemotongan/pemanenan dan penim- bangan serta penghitungan persen penutupan pada setiap plot pengamatan yang dibuat.

\section{Analisis Data}

Parameter yang diukur dalam penelitian ini yaitu keanekaragaman tumbuhan bawah dan kandungan karbonnya, kemudian dianalisis untuk menentukan jenis-jenis tumbuhan bawah yang dominan yaitu jenis yang mempunyai nilai penting tertinggi di dalam plot (Romadhon, 2008; Saleha \& Ngakan, 2016). Jenis-jenis tumbuhan bawah yang ada dalam plot dipisahkan dan ditimbang. Identifikasi jenis tumbuhan bawah dilakukan di Herbarium Botani, Pusat Litbang Hutan, Bogor. Untuk mengetahui berat kering, contoh dimasukkan dalam kantung kertas dan dikeringtanurkan pada suhu $85^{\circ} \mathrm{C}$ selama 48 jam. Penentuan jenis dominansi digunakan rumus Indeks nilai penting $(\mathrm{INP})=$ dominansi relatif + frekuensi relatif (Soerianegara \& Indrawan, 2008; Mirmanto, 2009; Istomo \& Pradiastoro, 2010).

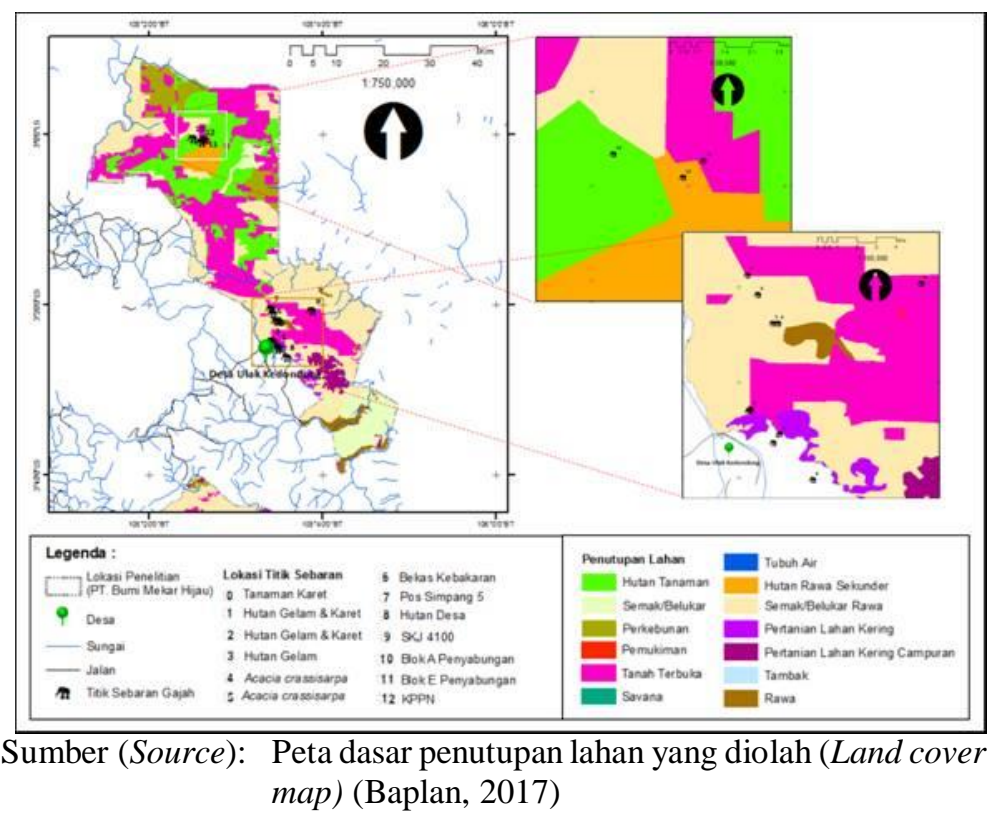

Gambar (Figure) 1. Lokasi penelitian (The research site) 
Untuk menentukan parameter yang dianalisis, digunakan formula sebagai berikut:

1. Indeks dominansi dipergunakan rumus Dombois \& Ellenberg (2016). Nilai dominansi jenis tertinggi 1 (satu) dan terendah 0 (nol), semakin mendekati 1 semakin dominan.

$$
C=\sum_{i=1}^{n}\left(\frac{n i}{N}\right)^{2}
$$

Dimana: $\mathrm{ni}=$ nilai penting masing-masing spesies, $\mathrm{N}=$ total nilai penting, dan $\mathrm{C}=$ indeks dominansi

2. Besarnya keragaman jenis tumbuhan digunakan nilai Shanon indeks $(\mathrm{H})$. Jika $\mathrm{H}$ tinggi mendekati 4 semakin beragam komunitas tumbuhan.

$$
H=-\sum_{i=1}^{n}\left(\frac{n i}{N}\right) \log \left(\frac{n i}{N}\right)
$$

Dimana $:$ ni $=$ nilai penting masingmasing spesies, $\mathrm{N}=$ total nilai penting, dan $\mathrm{H}=$ Shanon indeks

3. Berat kering contoh digunakan rumus Aoyama et al. (2011) sebagai berikut. $\mathrm{BKT}=\frac{\mathrm{BKC}}{\mathrm{BBC}} \times \mathrm{BBT}$

Dimana : $\mathrm{BKT}=$ berat kering total $(\mathrm{kg})$, $\mathrm{BKC}=$ berat kering contoh (gram), $\mathrm{BBC}=$ berat basah contoh (gram), dan BBT = berat basah total $(\mathrm{kg})$

4. Kandungan karbon dalam tumbuhan bawah dihitung dengan menggunakan rumus umum IPCC (2014).

Kandungan karbon $=$ Berat Kering Tanur Tumbuhan bawah $\times$ 0,5

5. Perhitungan produktivitas diketahui melalui pemotongan tumbuhan bawah yang diikuti dengan penimbangan
R. Garsetiasih, Anita Rianti dan N.M. Heriyanto

setiap 30 hari pada plot yang dipagar. Pemotongan (pemanenan) dilakukan tiga kali dengan waktu yang digunakan selama tiga bulan berturut-turut.

6. Perhitungan persentase penutupan dilakukan pada petak contoh ukuran $1 \mathrm{x} \quad 1 \mathrm{~m}$ saat dilakukan analisis vegetasi. Persentase penutupan dihitung berdasarkan jenis tumbuhan bawah yang ditemukan di setiap plot penelitian, yang menutupi petak contoh ukuran 1 x $1 \mathrm{~m}$ yang didalam-nya terdiri dari petak-petak ukuran $4 \mathrm{~cm}$ persegi. Persentase penutupan merupakan penjumlahan jenis tumbuhan bawah yang ditemukan dibagi jumlah keseluruhan di kali 100\%. Persentase penutupan terdiri dari tiga kategori yaitu jarang $(<40 \%)$, sedang (lebih dari 40 sampai kurang dari $60 \%$ ), dan rapat $(\geq 60 \%)$.

\section{HASIL DAN PEMBAHASAN}

A. Hasil

1. Komposisi dan dominansi jenis

Dominansi tumbuhan bawah di lokasi penelitian disajikan pada Tabel 1 . Dari Tabel 1 dapat dikemukakan bahwa jenis tumbuhan bawah yang mendominasi tegakan di lokasi penelitian yaitu paku harupat (N. biserrata) dengan indeks nilai penting sebesar $66,90 \%$ diikuti jenis harendong (M. malabathricum) sebesar $44,14 \%$ dan jenis paku udang (S. palustris) sebesar $36,18 \%$. Indeks keragaman tertinggi berturut-turut yaitu paku harupat (N. biserrata), harendong (M. malabathricum) dan paku udang (S. palustris) dengan indeks keragaman sebesar 0,37; 0,33; dan 0,31. Keadaan tumbuhan bawah di lokasi penelitian ditunjukkan pada Gambar 2. 
Tabel (Table) 1. Dominansi jenis tumbuhan bawah di lokasi penelitian (Dominancy of understorey species at the reseach site)

\begin{tabular}{|c|c|c|c|c|}
\hline No. & Jenis (Species) & Nama botani (Botanical name) & $\begin{array}{c}\text { INP (IVI) } \\
(\%)\end{array}$ & $\mathrm{H}^{\prime}$ \\
\hline 1. & Paku harupat & Nephrolepis biserrata (Sw.) Schott & 66,90 & 0,37 \\
\hline 2. & Paku udang & Stenochlaena palustris (Burm. f.) Bedd. & 36,18 & 0,31 \\
\hline 3. & Ilat/teki rawa & Cyperus kyllinga Endl. & 13,53 & 0,18 \\
\hline 4. & Harendong & Melastoma malabathricum $\mathrm{L}$. & 44,14 & 0,33 \\
\hline 5. & Areuy Pakis & Endrospermum sp. & 13,69 & 0,18 \\
\hline 6. & Pacing & Costus speciosus (J.Konig) Sm. & 6,96 & 0,12 \\
\hline 7. & Pandan & Pandanus atrocarpus Griff. & 12,40 & 0,17 \\
\hline \multirow[t]{2}{*}{8.} & Krokot & Portulaca oleracea L. & 6,20 & 0,11 \\
\hline & & Jumlah (Total) & 200,00 & 1,77 \\
\hline
\end{tabular}

$\overline{\text { Keterangan (Remarks): INP = Indeks Nilai Penting (Important Value Index }), \mathrm{H}^{\prime}=\text { Indeks keragaman }}$ (Biodiversity index)

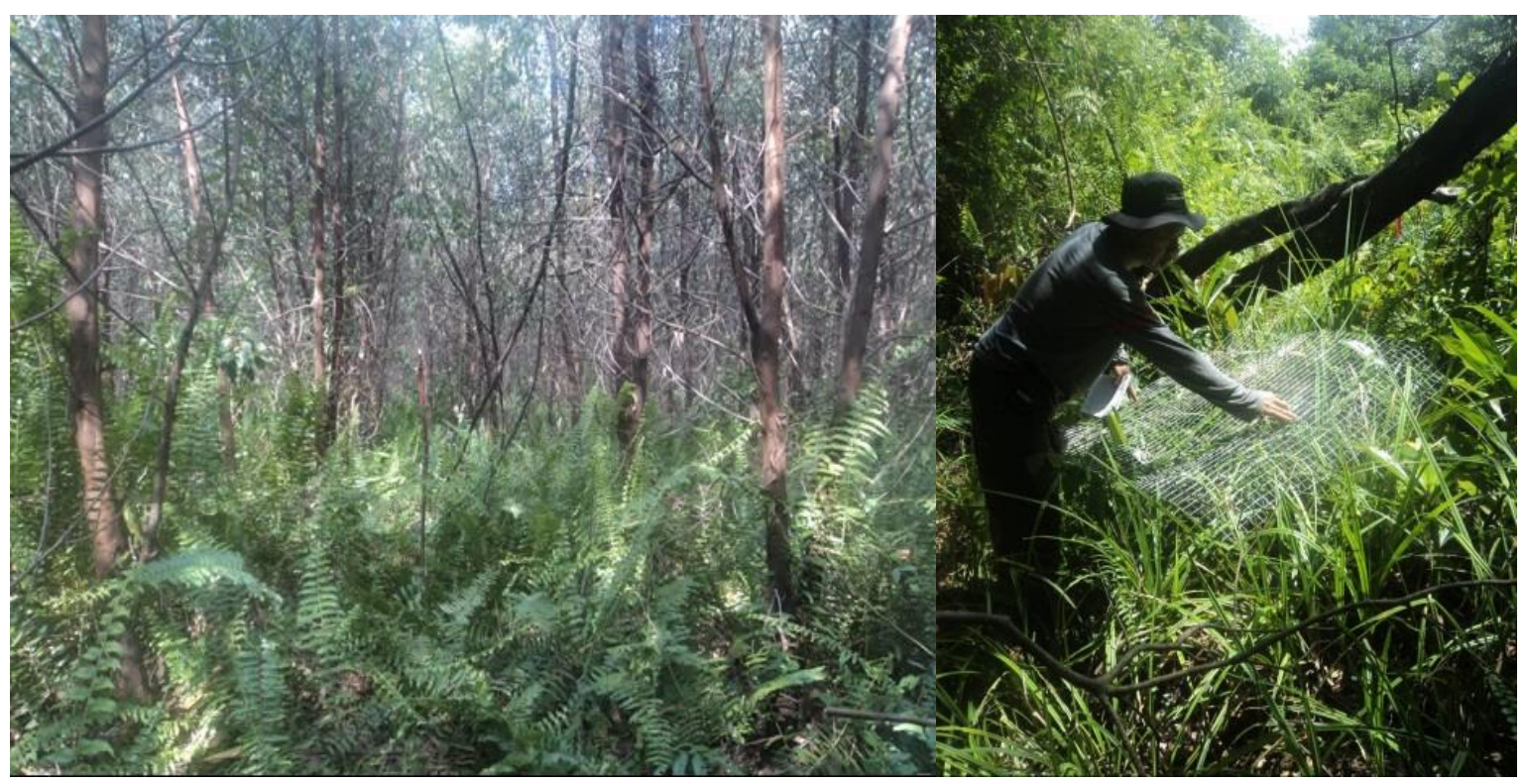

Gambar (Figure) 2. Keadaan tumbuhan bawah di lokasi penelitian (Understorey condition at the reseach site)

\section{Keanekaragaman jenis tumbuhan} bawah

Nilai indeks dominansi, keanekaragaman jenis dan jumlah jenis tumbuhan bawah di lokasi penelitian di Blok A (A. crassicarpa umur 3 tahun), Blok E (A. crassicarpa umur 3,3 tahun) dan di hutan alam sekunder Kawasan Pelestarian Plasma Nutfah (KPPN) disajikan pada Tabel 2. 
Tabel (Table) 2. Indeks dominansi keanekaragaman dan jumlah jenis tumbuhan bawah di lokasi penelitian (Dominancy of diversity index and number of understorey species at the research site)

\begin{tabular}{|c|c|c|c|c|}
\hline No & Areal hutan (Forest area) & $\begin{array}{l}\text { Indeks } \\
\text { dominansi } \\
\text { (Dominancy } \\
\text { index) }\end{array}$ & $\begin{array}{l}\text { Keanekaragaman } \\
\text { jenis (Species } \\
\text { diversity) }\end{array}$ & $\begin{array}{l}\text { Jumlah } \\
\text { jenis } \\
\text { (Species } \\
\text { number) }\end{array}$ \\
\hline 1. & Blok A (A. crassicarpa umur 3 tahun) & 0,1124 & 0,9351 & 5 \\
\hline 2. & Blok E (A. crassicarpa umur 3,3 tahun) & 0,1512 & 0,9332 & 4 \\
\hline 3. & $\begin{array}{l}\text { Kawasan Pelestarian Plasma Nutfah } \\
\text { (KPPN) }\end{array}$ & 0,1611 & 0,9456 & 8 \\
\hline Keter & $\begin{array}{ll}\operatorname{gan}(\text { Remarks): } & \text { Blok A = A. crassicarpa ur } \\
& \text { KPPN = Kawasan Pelesta } \\
& \text { planted, Block E = } \text { A. crass } \\
& \text { of Germplasm })\end{array}$ & $\begin{array}{l}\text { tahun, Blok } \\
\text { Plasma Nutf } \\
3.3 \text { year pl }\end{array}$ & $\begin{array}{l}\text { A. crassicarpa um } \\
\text { Block } A=\underline{\text { Ala }} \text { cra } \\
d \text {, and } K P P N=C o\end{array}$ & $\begin{array}{l}3,3 \text { tahun de } \\
\text { carpa } 3 \text { yee } \\
\text { rvation Are }\end{array}$ \\
\hline
\end{tabular}

Dari Tabel 2 di atas dapat dikemukakan bahwa hasil perhitungan derajat keanekaragaman jenis dari komunitas tumbuhan bawah pada tegakan A. crassicarpa tidak terlalu berbeda. Tetapi jika dibandingkan pada tegakan umur 3 tahun di blok A dan umur 3,3 tahun di blok E dengan di Kawasan Pelestarian Plasma Nutfah (KPPN) keragaman jenisnya relatif berbeda dan di KPPN jumlahnya lebih banyak dibandingkan dengan tumbuhan bawah pada tegakan umur 3 tahun dan 3,3 tahun.

\section{Biomassa dan kandungan karbon}

Kandungan karbon pada tanaman menggambarkan berapa besar tanaman tersebut mengikat karbondioksida dari udara. Sebagian karbon akan menjadi bahan bakar untuk proses hidup tanaman dan sebagian masuk dalam struktur tumbuhan dan menjadi bagian dari tumbuhan, misalnya selulosa. Menurut IPCC (2013), bahwa 45\% sampai 50\% bahan kering tanaman terdiri dari kandungan karbon, sedangkan kandungan air tumbuhan bawah berkisar antara $65,43-76,25 \%$ atau rata-rata $72,65 \%$. Biomasa dan kandungan karbon tumbuhan bawah di lokasi penelitian disajikan pada Tabel 3 .

Pada Tabel 3 dapat dikemukakan produktivitas atau biomassa jenis paku harupat (N. biserrata) menempati posisi tertinggi terutama di blok A (umur tanaman A. crassicarpa 3 tahun), hal ini dapat dijelaskan bahwa tumbuhan bawah tersebut memerlukan kelembaban yang tinggi dan intensitas cahaya yang relatif rendah untuk dapat tumbuh dengan optimal sehingga dapat menguasai/ mendominasi biomassa di tempat tersebut. Hal ini sesuai dengan Kuswata (2016), yang menyatakan bahwa tumbuhan akan tumbuh dengan optimal apabila menempati habitat yang sesuai terutama suhu dan kelembaban.

\section{Produktivitas tumbuhan bawah sebagai pakan satwa herbivora}

Tumbuhan bawah di lokasi penelitian hutan produksi terbatas Distrik Penyabungan berupa Hutan Tanaman Indonesia (HTI) jenis A. crassicarpa selain berfungsi sebagai stok karbon juga berfungsi sebagai pakan satwa herbivora. Di lokasi penelitian terdapat beberapa satwa liar herbivora khususnya payau/rusa sambar (Rusa unicolor equinus) dan gajah (E. maximus sumatranus). Kedua satwa tersebut memanfaatkan tumbuhan bawah sebagai hijauan pakan di Hutan Kawasan Pelestarian Plasma Nutfah (KPPN) dan hutan produksi A. crassicarpa. Untuk mengetahui potensi tumbuhan bawah dan jenis hijauan pakan satwa herbivora 
dilakukan pengukuran produktivitas pada plot penelitian yang sama setiap 30 hari dengan 3 kali pengukuran, besarnya produktivitas diketahui dengan cara pemanenan/pemotongan dan ditimbang berat produksinya. Pengamatan dan pengukuran produktivitas tumbuhan bawah dilakukan pada saat musim kemarau yaitu bulan Agustus sampai awal November 2017. Hasil pengukuran produktivitas ditunjukkan pada Tabel 4, 5 dan 6 berikut:

Tabel (Table) 3. Biomassa dan kandungan karbon tumbuhan bawah di lokasi penelitian (Biomass and carbon content of understorey at the research site)

\begin{tabular}{|c|c|c|c|c|c|c|c|}
\hline \multirow[b]{3}{*}{ No } & \multirow[b]{3}{*}{ Jenis (Species) } & \multicolumn{6}{|c|}{ Lokasi (Location) } \\
\hline & & \multicolumn{2}{|c|}{ Blok A } & \multicolumn{2}{|c|}{ Blok E } & \multicolumn{2}{|c|}{ KPPN } \\
\hline & & $\begin{array}{c}\text { Biomassa } \\
\text { (Biomass) } \\
(\mathrm{kg} / \mathrm{ha})\end{array}$ & $\begin{array}{c}\text { Kandungan } \\
\text { karbon } \\
\text { (Carbon } \\
\text { content) } \\
\text { (kg C/ha) }\end{array}$ & $\begin{array}{c}\text { Biomassa } \\
\text { (Biomass) } \\
\text { (kg/ha) }\end{array}$ & $\begin{array}{c}\text { Kandungan } \\
\text { karbon } \\
\text { (Carbon } \\
\text { content) } \\
(\mathrm{kg} \mathrm{C} / \mathrm{ha})\end{array}$ & $\begin{array}{c}\text { Biomassa } \\
\text { (Biomass) } \\
(\mathrm{kg} / \mathrm{ha})\end{array}$ & $\begin{array}{c}\text { Kandungan } \\
\text { karbon } \\
\text { (Carbon } \\
\text { content) } \\
\text { (kg C/ha) }\end{array}$ \\
\hline 1 & $\begin{array}{l}\text { Paku harupat (N. } \\
\text { biserrata) }\end{array}$ & 429,52 & 214,76 & 262,94 & 131,47 & 128,65 & 64,32 \\
\hline 2 & $\begin{array}{l}\text { Paku udang (S. } \\
\text { palustris) }\end{array}$ & 51,85 & 25,92 & 57,27 & 28,63 & 60,64 & 30,32 \\
\hline 3 & $\begin{array}{l}\text { Ilat/teki rawa (C. } \\
\text { kyllinga) }\end{array}$ & 26,64 & 13,32 & - & - & 64,29 & 32,14 \\
\hline 4 & $\begin{array}{l}\text { Harendong (M. } \\
\text { malabathricum) }\end{array}$ & 44,94 & 22,47 & 34,72 & 17,36 & 5,83 & 2,91 \\
\hline 5 & $\begin{array}{l}\text { Areuy pakis } \\
\text { (Endrospermum } \\
\text { sp.) }\end{array}$ & 8,85 & 4,42 & 16,55 & 8,27 & 5,94 & 2,97 \\
\hline 6 & $\begin{array}{l}\text { Pacing }(\mathrm{C} . \\
\text { speciosus })\end{array}$ & - & - & - & - & 28,88 & 14,44 \\
\hline 7 & $\begin{array}{l}\text { Pandan } \\
\text { (Pandanus } \\
\text { atrocarpus) }\end{array}$ & - & - & - & - & 67,82 & 33,91 \\
\hline 8 & $\begin{array}{l}\text { Krokot } \\
\text { (Portulaca } \\
\text { oleracea) }\end{array}$ & - & - & - & - & 21,79 & 10,89 \\
\hline & Jumlah (Total) & 561,8 & 280,90 & 371,48 & 185,74 & 383,84 & 191,92 \\
\hline
\end{tabular}

Tabel (Table) 4. Produktivitas jenis tumbuhan bawah pada Akasia umur 3 tahun di Distrik Sungai Penyabungan (Productivity of understorey species at 3 year old Acacia plantation in Sungai Penyabungan Districts)

\begin{tabular}{|c|c|c|c|c|c|}
\hline No. & Jenis (Species) & $\begin{array}{c}\text { Nama ilmiah (Botanical } \\
\text { name) }\end{array}$ & $\begin{array}{c}l \quad \text { Persentase } \\
\text { penutupan } \\
\text { (Cover percentage) } \\
(\%)\end{array}$ & $\begin{array}{c}\text { Rata-rata } \\
\text { biomassa } \\
\text { (Average } \\
\text { biomass) } \\
(\mathrm{kg} / \mathrm{ha})\end{array}$ & $\begin{array}{l}\text { Rata-rata } \\
\text { produktivitas } \\
\text { (Average } \\
\text { productivity) } \\
\text { ( } \mathrm{kg} / \mathrm{ha} / \text { hari) }\end{array}$ \\
\hline 1 & Areuy pakis & Endrospermum sp. & 3,25 & 175,00 & 0,00 \\
\hline 2 & Harendong & M. malabatricum & 1,13 & 110,00 & 0,00 \\
\hline 3 & Ilat/ Teki rawa & C. kyllinga & 4,40 & 884,00 & 0,00 \\
\hline 4 & Paku harupat & N. biserrata & 25,73 & $5.167,14$ & 105,44 \\
\hline 5 & Paku udang & S. palustris & 3,57 & 675,00 & 18,67 \\
\hline 6 & Anggerit & Nauclea lanceolata Bl. & 3,25 & 100,00 & 0,00 \\
\hline \multicolumn{3}{|c|}{ Jumlah (Total) } & 41,33 & $7.111,14$ & 124,11 \\
\hline
\end{tabular}


Tabel (Table) 5. Produktivitas jenis tumbuhan bawah pada areal KPPN Distrik Sungai Penyabungan (Productivity of understorey species at KPPN area Sungai Penyabungan Districts)

\begin{tabular}{cllccc}
\hline No. & Jenis (Species) & $\begin{array}{c}\text { Nama ilmiah } \\
\text { (Botanical name })\end{array}$ & $\begin{array}{c}\text { Persentase } \\
\text { penutupan } \\
\text { Cover percentage }) \\
(\%)\end{array}$ & $\begin{array}{c}\text { Rata-rata } \\
\text { biomassa } \\
\text { (Average } \\
\text { biomass) } \\
(\mathrm{kg} / \mathrm{ha})\end{array}$ & $\begin{array}{c}\text { Rata-rata } \\
\text { produktivitas } \\
\text { Average productivity) } \\
\text { (kg/ha/hari) } \\
(\mathrm{kg} / \mathrm{ha} / \text { days })\end{array}$ \\
\hline 1 & Areuy pakis & Endrospermum sp. & 6,50 & 101,00 & 0,00 \\
2 & Harendong & M. malabathricum & 0,75 & 6,00 & 0,00 \\
3 & Ilat/ Teki rawa & C. kyllinga & 16,00 & $1.060,00$ & 15,56 \\
4 & Krokot & Portulaca oleracea. & 1,42 & 30,00 & 0,00 \\
5 & Pacing & C. speciosus. & 2,83 & 138,67 & 0,00 \\
6 & Paku harupat & N. biserrata & 40,33 & 577,40 & 25,78 \\
7 & Paku udang & S. palustris & 3,34 & 127,88 & 49,89 \\
8 & Pandan & P. atrocarpus. & 13,33 & 326,67 & 3,89 \\
9 & Salak Hutan & Salacca affinis & 9,00 & 136,00 & 0,00 \\
\hline \multicolumn{2}{c}{ Jumlah (Total) } & 93,5 & $1.443,62$ & 95,12 \\
\hline
\end{tabular}

Tabel (Table) 6. Produktivitas jenis tumbuhan bawah pada (Akasia umur 3 tahun 3 bulan) di Distrik Sungai Penyabungan (Productivity of understorey species at 3,3 year old Acacia plantation at Sungai Penyabungan Districts)

\begin{tabular}{cllrrr}
\hline No. & Jenis (Species) & $\begin{array}{c}\text { Nama ilmiah } \\
\text { (Botanical name) }\end{array}$ & $\begin{array}{c}\text { Persentase } \\
\text { penutupan (Cover } \\
\text { of percentage }) \\
(\%)\end{array}$ & $\begin{array}{c}\text { Rata-rata } \\
\text { biomassa } \\
\text { (Average } \\
\text { biomass) } \\
(\mathrm{kg} / \mathrm{ha})\end{array}$ & $\begin{array}{c}\text { Rata-rata } \\
\text { produktivitas } \\
\text { (Average } \\
\text { productivity) } \\
\text { (kg/ha/hari) }\end{array}$ \\
\hline 1 & Areuy pakis & Endrospermum sp, & 3,38 & 33,00 & 0,00 \\
2 & Harendong & M. malabathricum & 2,50 & 17,00 & 0,00 \\
3 & Paku harupat & N. biserrata & 15,23 & 308,36 & 21,04 \\
4 & Paku udang & S. palustris & 6,23 & 107,33 & 5,36 \\
5 & Pandan & P. atrocarpus. & 2,42 & 18,67 & 4,44 \\
6 & Ilat/Teki rawa & C. kyllinga & 1,25 & 1,00 & 0,00 \\
\hline & Jumlah (Total) & & 31,01 & 485,36 & 30,84
\end{tabular}

\section{B. Pembahasan}

1. Komposisi dan dominasi jenis

Jenis dominan menunjukkan bahwa jenis yang dapat memanfaatkan lingkungan yang di tempatinya secara efisien daripada jenis lain dalam tempat yang sama (Kartawinata, 2016). Dari pernyataan ini, maka jenis pakis paku harupat (N. biserrata), harendong (M. malabathricum), dan pakis paku udang (S. palustris) adalah jenis-jenis tumbuhan bawah di lokasi penelitian yang paling dapat memanfaatkan lingkungan dengan baik atau kondisi tempat tumbuhnya paling sesuai.

\section{Keanekaragaman jenis tumbuhan bawah}

Nilai keragaman jenis tumbuhan bawah termasuk dalam kategori rendah. Hal ini dikarenakan tegakan A. crassicarpa secara periodik dipanen/ ditebang yang menyebabkan tumbuhan bawahnya terganggu, sehingga keragam- 
an jenis menjadi rendah. Kartawinata (2013) menyatakan bahwa masyarakat tumbuhan pada hutan hujan tropis mempunyai derajat keragaman jenis yang lebih tinggi dan derajat penguasaan jenis yang rendah. Masyarakat tumbuhan yang sering mendapat gangguan dari manusia atau alam akan mempunyai keragaman jenis kecil dan derajat penguasaan jenis besar. Keragaman jenis tumbuhan bawah pada tegakan A. crassicarpa umur 3,3 tahun (Blok E) merupakan yang paling kecil, hal ini dimungkinkan karena tajuknya lebih rapat sehingga cahaya yang masuk ke lantai hutan kurang, sedangkan tumbuhan bawah membutuhkan cahaya matahari.

Dombois \& Ellenberg (2016) menyatakan bahwa, nilai indeks keanekaragaman jenis menggambarkan tingkat keanekaragaman jenis dalam suatu komunitas tumbuhan. Bila nilai ini semakin tinggi, maka semakin meningkat keanekaragamannya dalam komunitas tersebut. Indeks dominansi (ID) menggambarkan pola dominansi jenis dalam suatu tegakan. Nilai ID tertinggi satu, yang menunjukkan bahwa tegakan tersebut dikuasai satu jenis atau terpusat pada satu jenis. Makin kecil ID, maka pola dominansi jenisnya semakin menyebar pada beberapa jenis yang dominan. Jadi nilai ID dapat dijadikan indikator untuk mengetahui terpusat atau tidaknya dominansi jenis dalam suatu tegakan. Dengan demikian, penguasaan jenis tumbuhan bawah pada tegakan Kawasan Pelestarian Plasma Nutfah (KPPN) lebih besar $(0,1611)$ dibandingkan pada tegakan di blok A dan blok E $(0,1124$ dan 0,1512). Hal ini diduga karena tegakan di KPPN relatif tidak terganggu oleh aktivitas manusia dan keadaan tegakannya lebih terbuka dibandingkan dengan hutan tanaman di dua tempat tersebut, sehingga menyebabkan dominansi terpusat di ketiga jenis tumbuhan bawah tersebut yaitu paku harupat (N. biserrata), harendong (M. malabathricum), dan paku udang (S. palustris).

\section{Biomassa dan kandungan karbon}

Berdasarkan Tabel 3 di atas dapat dikemukakan bahwa dari delapan jenis tumbuhan bawah di lokasi penelitian, berat biomassa kering dan kandungan karbon yang paling tinggi yaitu berturutturut paku harupat (N. biserrata di blok A sebesar 429,52 kg/ha atau 214,76 kg C/ha, pandan (P. atrocarpus) di KPPN sebesar 67,82 kg/ha atau 33,91 $\mathrm{kg}$ C/ha dan rumput ilat (C. kyllinga) di KPPN sebesar $64,29 \mathrm{~kg} / \mathrm{ha}$ atau 32,14 kg C/ha. Berat kering total tumbuhan bawah di blok A, blok E dan KPPN berturut-turut adalah $561,8 \mathrm{~kg} ; 371,48 \mathrm{~kg}$; dan 383,84 kg. Bila dibandingan dengan hutan tanaman A. crassicarpa umur 3 tahun, biomassa dan kandungan karbon yang dihitung berdasarkan pendekatan volume dan berat jenis kayu yaitu sebesar 22,35 ton/ha atau 11,17 ton $\mathrm{C} / \mathrm{ha}$. Dengan demikian, kontribusi tumbuhan bawah tersebut dalam menyimpan karbon sebesar 5-6\% dibanding tegakan tersebut.

Hasil penelitian Ariani, Sudhartono, \& Wahid (2014) di sekitar Danau Tambing Taman Nasional Lore Lindu, menunjukkan nilai berat kering total yang tidak berbeda jauh dengan penelitian ini yaitu biomassa tumbuhan bawahnya maksimal sebesar 1,13 ton/ha. Hal ini kemungkinan karakteristik tempat tumbuh kedua lokasi yang hampir sama yaitu pada lahan yang lembab. Hasil perhitungan tersebut, dengan jumlah kandungan karbon sebesar 589,28 $\mathrm{kg} \quad \mathrm{C}$ dapat dinyatakan bahwa tumbuhan bawah pada lokasi penelitian berperan dalam menyerap karbondioksida $\left(\mathrm{CO}_{2}\right)$ dari udara dalam memperbaiki iklim mikro.

\section{Produktivitas tumbuhan bawah sebagai pakan satwa herbivora}

Tabel 4, 5, dan 6 menunjukkan bahwa produktivitas tumbuhan bawah di atas yang paling tinggi produktivitasnya di 
lokasi blok A yaitu tumbuhan di bawah tegakan A. crassicarpa umur tiga tahun sebesar 125,44 $\mathrm{kg} / \mathrm{ha} / \mathrm{hari}$ dengan persentase penutupan kategori sedang $(47,96 \%)$. Produktivitas tumbuhan bawah terendah di blok E yaitu di bawah tegakan A. crassicarpa umur 3,3 tahun dengan produktivitas rata-rata sebesar 30,84 $\mathrm{kg} / \mathrm{ha} / \mathrm{hari}$ dan persen penutupan kategori jarang $(31,01 \%)$. Hal ini dimungkinkan karena tumbuhan bawah tidak dapat tumbuh secara maksimal jika ternaungi tajuk pohon yang menyebabkan kurangnya cahaya matahari (Kartawinata, 2013). Kebutuhan hijauan pakan gajah Sumatera dewasa sekitar $250 \mathrm{~kg}$ per hari (Mahanani, Hendrarto, \& Suprobowati, 2012) dan ada tiga jenis tumbuhan bawah yang disukai gajah yaitu pakis harupat, areuy pakis dan ilat/teki rawa. Blok A dan E memiliki luasan 25 ha, sedangkan areal KPPN memiliki luasan 480 ha, sehingga daya dukung dalam menyediakan pakan gajah pada saat musim kemarau di blok A adalah 10,54 gajah; blok E sebanyak 2,10 ekor gajah; dan areal KPPN sebanyak 79,37 gajah.

Produktivitas tumbuhan bawah di Kawasan Pelestarian Plasma Nutfah lebih tinggi yaitu $95,12 \mathrm{~kg} / \mathrm{ha} / \mathrm{hari}$ dibandingkan di bawah tegakan A. crassicarpa umur 3,3 tahun sebesar 30,84 kg/ha/hari. Hal ini disebabkan kerapatan tegakan di hutan KPPN rendah yaitu 135 pohon/ha, sedangkan di areal hutan tanaman 1.300 pohon/ha, selain itu terdapat beberapa jenis tumbuhan bawah yang tidak tumbuh kembali setelah dilakukan pemanenan yang diduga jenis-jenis tersebut pertumbuhannya lambat, sehingga memiliki nilai produktivitas $0 \mathrm{~kg} / \mathrm{ha} / \mathrm{hari}$. Satwa gajah dalam aktivitasnya lebih banyak memanfaatkan areal KPPN karena selain produktivitas hijauan pakannya tinggi juga keragaman vegetasi tumbuhan bawahnya lebih variatif daripada di hutan tanaman, sehingga lebih banyak pilihan. Seperti sudah dikemukakan sebelumnya bahwa tidak semua jenis tumbuhan bawah di lokasi penelitian dimakan gajah, sehingga tumbuhan bawah bisa tetap berfungsi sebagai penyimpan karbon.

Keragaman jenis dan produktivitas tumbuhan bawah yang relatif tinggi di lokasi penelitian dapat memenuhi keberlangsungan hidup satwa gajah dan berkontribusi dalam menyimpan karbon. Hutan tanaman A. crassicarpa dengan kerapatan yang tinggi selain untuk tempat mencari makan juga dijadikan tempat beristirahat oleh satwa gajah, sedangkan hutan KPPN yang mempunyai luas 480 ha sebagian besar dimanfaatkan sebagai tempat mencari makan dan bermain terutama pada areal yang terbuka. Satwa gajah dalam melakukan aktivitas hariannya membutuhkan areal terbuka sebagai tempat mencari pakan, sedangkan areal yang ada naungannya digunakan sebagai tempat beristirahat (Abdullah, Asiah, \& Japisa, 2012). Untuk memenuhi kebutuhan hijauan pakan, gajah juga memanfaatkan tumbuhan bawah serta tanaman A. crassicarpa muda, di luar areal KPPN.

\section{Implikasi terhadap pengelolaan areal HTI}

Pengelolaan areal HTI yang di dalamnya juga merupakan habitat satwa liar termasuk gajah harus memasukkan unsur-unsur kesejahteraan bagi satwa liar dalam pengelolaannya. Saat ini di dalam areal hutan produksi khususnya HTI masih dimanfaatkan oleh satwa liar sebagai habitat dan sebagian dari perusahaan HTI tersebut sudah melakukan upaya perlindungan terhadap keberlangsungan biodiversitas dengan cara menunjuk, membangun dan mengelola suatu kawasan berupa High Conservation Value Forest (HCVF) atau Kawasan Pelestarian Plasma Nutfah (KPPN) sebagai tanda kepedulian terhadap keberlangsungan terhadap nilai-nilai konservasi dari ekosistem flora fauna atau lingkungan secara umum yang ada dalam areal yang menjadi tanggung jawab 
perusahaan dalam pengelolaannya. Pengelolaan areal hutan produksi dalam hal ini berupa hutan tanaman monokultur jenis A. crassicarpa, dibutuhkan suatu sistem pengelolaan yang mempertimbangkan keberlangsungan fungsi ekosistem.

Dalam areal hutan tanaman A. crassicarpa yang dijadikan lokasi penelitian terdapat satwa liar khususnya gajah, sehingga untuk melindunginya perlu upaya peningkatan kualitas KPPN. Pada hutan tanaman A. crassicarpa khususnya kelas umur muda masih terdapat tumbuhan bawah yang mempunyai potensi sebagai penyimpan karbon dan juga dimanfaatkan oleh gajah sebagai hijauan pakan. Peningkatan kualitas KPPN untuk memenuhi kebutuhan hidup satwaliar khususnya gajah dapat dilakukan melalui restorasi, pembuatan koridor atau pengkayaan jenis-jenis tanaman yang dibutuhkan dan disukai oleh gajah. Jika hal ini dilakukan, tingkat gangguan gajah terhadap tanaman $\mathrm{A}$. crassicarpa muda dan tumbuhan bawah yang mempunyai fungsi sebagai penyimpan karbon dapat diminimalisir. Untuk tanaman A. crassicarpa kelas umur empat tahun ke atas tumbuhan bawahnya sudah mulai berkurang karena kurangnya cahaya matahari, sehingga jarang didatangi satwa liar herbivora gajah.

\section{KESIMPULAN DAN SARAN}

\section{A. Kesimpulan}

Terdapat delapan jenis tumbuhan bawah yang ditemukan di lokasi penelitian dan didominasi oleh paku harupat (N. biserrata) dengan indeks nilai penting $66,90 \%$, harendong $(\mathrm{M}$. malabathricum) 44,14\%, dan jenis paku udang (S. palustris) 36,18\%. Derajat keragaman jenis tumbuhan bawah sebesar 0,$935 ; 0,933$; dan 0,946 dengan jumlah jenis masing-masing 7, 6, dan 8 jenis. Keragaman jenis tertinggi terdapat di hutan alam sekunder yang berupa KPPN, keragaman jenis tumbuhan bawah tersebut termasuk dalam kategori rendah. Biomassa tumbuhan bawah di blok A (tegakan A. crassicarpa 3 tahun), blok E (tegakan A. crassicarpa 3,3 tahun) dan KPPN berturut-turut adalah $561,8 \mathrm{~kg} / \mathrm{ha}$; $371,48 \mathrm{~kg} / \mathrm{ha} ;$ dan $383,84 \mathrm{~kg} / \mathrm{ha}$. Tumbuhan bawah di hutan KPPN mempunyai nilai produktivitas yang tinggi dibanding di hutan tanaman A. crassicarpa umur 3-3,3 tahun dan dimanfaatkan gajah sebagai tempat mencari makan dan bermain. Hutan tanaman sebagian besar dimanfaatkan sebagai tempat beristirahat dan tidur serta sebagian kecil sebagai tempat mencari makan, terutama pada tanaman A. crassicarpa kelas umur muda. Untuk meminimalisir gangguan gajah pada tanaman A. crassicarpa kelas umur muda serta fungsinya sebagai penyimpan karbon, perlu dilakukan upaya peningkatan kualitas KPPN melalui restorasi, pengkayaan tanaman pakan, serta pembangunan koridor pada daerah jelajah gajah.

\section{B. Saran}

Topografi di lokasi penelitian termasuk datar dengan jenis tanah gambut, sehingga untuk mengurangi emisi karbon pada tanah terbuka harus diupayakan adanya tumbuhan bawah untuk menghindari kebakaran. Pengaturan pemanenan tanaman pokok perlu dilakukan dengan mempertim-bangkan keberadaan tumbuhan bawah, karena tumbuhan bawah berperan sebagai hijauan pakan satwa herbivora seperti gajah, menyimpan karbondioksida, dan memperbaiki iklim mikro. Perlu pengayaan dengan jenis-jenis lokal, di hutan KPPN melalui restorasi untuk mempercepat proses suksesi.

\section{UCAPAN TERIMA KASIH}

Penulis mengucapkan terima kasih kepada manajemen dan staf PT. Bumi Mekar Hijau (BMH) Sumatera Selatan, khususnya staf KPPN dan staf Distrik 
Sungai Penyabungan. Ucapan yang sama penulis sampaikan kepada Kepala dan staf Balai Konservasi Sumberdaya Alam (BKSDA) Sumatera Selatan dan teknisi kami dari Pusat Litbang Hutan khususnya Bapak Eman dan Bapak Carlan yang telah membantu dalam pelaksanaan kegiatan penelitian ini.

\section{DAFTAR PUSTAKA}

Abdiyani, S. (2008). Keanekaragaman jenis tumbuhan bawah berkhasiat obat di Dataran Tinggi Dieng. Jurnal Penelitian Hutan dan Konservasi Alam, 5(1), 79-92.

Abdullah, Asiah, \& Japisa, T. (2012). Karakteristik habitat gajah sumatera (Elephas maximus sumatranus) di kawasan ekosistem Seulawah, Kabupaten Aceh Besar. Jurnal Ilmiah Pendidikan Biologi, Biologi Edukasi, 4(1), 41-45.

Ariani, Sudhartono, A., \& Wahid, A. (2014). Biomassa dan karbon tumbuhan bawah sekitar Danau Tambing pada kawasan Taman Nasional Lore Lindu. Warta Rimba, 2(1), 164-170.

Aoyama, K., Yoshida, T., Harada, A., Noguchi, M., Miya, H., \& Shibata, H. (2011). Changes in carbon stock following soil scarification of nonwooded stands in Hokkaido, Northern Japan. Citation Journal of Forest Research, 16(1), 35-45.

Baccaro, G., Rocchini, D., Diekmann, M., Gasparini, P., Gioria, M., Maccherini, S., Marcantonia, M., Tordoni, E., Amici, V., Landi, S., Torri, D., Castello, M., Altobellu, A., \& Chiarucci, A. (2015). Shape matters in sampling plant diversity: evidence from field. Ecological Complexity, 24, 37-45.

Badan Pusat Statistik (BPS). (2016). Ogan Kemering Ilir (OKI) dalam Angka. Badan Pusat Statistik Ogan
Kemering Ilir. Propinsi Sumatera Selatan.

Badan Planologi Kehutanan. (2017). Peta Dasar Penutupan Lahan Indonesia. Kementerian Lingkungan Hidup dan Kehutanan.

Bismark, M., Heriyanto, N.M., \& Iskandar, S. (2008). Biomassa dan kandungan karbon pada hutan produksi di Cagar Biosfer Pulau Siberut, Sumatera Barat. Jurnal Penelitian Hutan dan Konservasi Alam, 5(5), 397-407.

Dharmawan, I.W.S., \& Samsoedin, I. (2012). Dinamika potensi biomassa karbon pada landskap hutan bekas tebangan di Hutan Penelitian Malinau. Jurnal Penelitian Sosial dan Ekonomi Kehutanan, 9(1), 1220.

Dombois, D.M., \& Ellenberg, H. (2016). Aims and Methods of Vegetation Ecology. John Wiley \& Sons. Inc. New York. USA.

Google Earth. (2017). Peta Digital Sumatera Selatan. Retrieved from www. google.com

Hidayat, D., \& Hardiansyah, G. (2012). Studi keanekaragaman jenis tumbuhan obat di kawasan IUPHHK PT. Sari Bumi Kisuma Camp Tontang, Kabupaten Sintang. Vokasi, 8(2), 61-68.

Indonesia National Carbon Accounting System [INCAS]. (2015). Indonesia Luncurkan Alat Baru Hadapi Perubahan Iklim. Program REDD-I. Hutan dan Perubahan Iklim di Indonesia. Kementerian Lingkungan Hidup dan Kehutanan Indonesia.

International Panel on Climate Change [IPCC]. (2013). Climate Change 2013 the Physical Basis Working Group I Contrubution to The Fifth Assessment Report of The IPCC. Switzerland. 
International Panel on Climate Change [IPCC]. (2014). Mitigation of Climate Change Contribution of Working Group III to The Fifth Assessment Report. Intergovermental -Panel on Climate Change Cambridge. Cambridge University Press.

Istomo, \& Pradiastoro, A. (2010). Karakteristik tempat tumbuh pohonpohon gunung (D. retusus) di kawasan hutan lindung $G$. Cakrabuana, Sumedang, Jabar. Jurnal Penelitian Hutan dan Konservasi Alam, 8(1), 1-12.

Kalima, T., \& Heriyanto, N.M. (2014). Keragaman jenis tumbuhan di Cagar Alam Gunung Celering. Buletin Plasma Nutfah, 20(1), 41-51.

Kartawinata, K., Partomihardjo, T., Yusuf, R., Abdulhadi, R., \& Riswan, S. (2008). Floristic and structure of lowland Dipterocarp forest at Wanariset Samboja, East Kalimantan, Indonesia. Reindwartia, 12 (4), 301-323.

Kartawinata, K. (2013). Diversitas Ekosistem Alami Indonesia. Yayasan Pustaka Obor Indonbesia \& LIPI Press, Jakarta. (In Indonesian).

Kartawinata, K. (2016). Diversitas Ekosistem Alami Indonesia. Yayasan Pustaka Obor Indonesia.

Lugina, M., Ginoga, K.L., Wibowo, A., Bainnaura, A., \& Partiani, T. (2011). Prosedur Operasi Standar (SOP) untuk Pengukuran Stok Karbon di Kawasan Konservasi. Pusat Penelitian dan Pengembangan Perubahan Iklim dan Kebijakan Badan Penelitian dan Pengembangan Kehutanan, Kementerian Kehutanan, Indonesia. Kerjasama dengan: International Tropical Timber Organization (ITTO).
Mahanani, A.I., Hendrarto. I.B., \& Suprobowati, T.R. (2012). Daya dukung gajah sumatera (Elephas maximus sumatranus Temminck) Di SM Padang Sugihan, Provinsi Sumatra Selatan. Prosiding Seminar Nasional. Pengelolaan SDA dan Lingkungan,28-30.

Masy'ud, B., Kusuma, I.H., \& Rachmandani, Y. (2008). Potensi vegetasi pakan dan efektivitas perbaikian habitat rusa timor (Cervus timorensis, de Blainville 1822) di Tanjung Pasir, Taman Nasional Bali Barat. Media Konservasi, 13(2), 59-64.

Mirmanto, E. (2009). Forest dynamics of peat swamp forest in Sebangau, Central Kalimantan. Biodiversitas, 10(4), 187 - 194.

Morikawa, Y. (2012). Biomass measurement in planted forest in and around Benakat, Fiscal report of assessment on the potentiality of reforestation and afforestation activities in mitigating the climate change, 2012, 58-63. JIFPRO.

Onrizal, Ismail, E.A., Perbatakusuma, H., Sudjito, J., Suprijatna, \& Wijayanto, I.H. (2008). Struktur vegetasi dan simpanan karbon hutan hujan primer di Batang Toru, Sumatera Utara. Jurnal Biologi Indonesia, 5(2), 187-199.

Onrizal \& Kusmana, C. (2009). Struktur dan keanekaragaman jenis mangrove pasca tsunami di Pulau Nias. Jurnal Berita Biologi, 9(4), 359-364.

Purwanta, W. (2010). Penghitungan emisi karbon dari lima sektor pembangunan berdasar metode IPCC dengan verifikasi faktor emisi dan data aktivitas lokal. Jurnal Teknologi Lingkungan, 11(1), 71 77.

Pusat Penelitian Tanah dan Agroklimat. (2013). Peta Tanah Pulau Sumatera. 

Benth sebagai Pakan Gajah dan Penyimpan Karbon di Kabupaten Ogan Komering Ilir

Badan Penelitian dan Pengembangan Pertanian. Departemen Pertanian. Bogor.

Romadhon, A. (2008). Kajian nilai ekologi melalui inventarisasi dan indeks nilai penting (INP) mangrove terhadap perlindungan lingkungan Kepulauan Kangean. Embryo, 5(1), $82-97$.

Saleha, S., \& Ngakan, P.O. (2016). Sebaran dan struktur populasi anakan Diospyros celebica Bakh. di bawah pohon induknya. Jurnal Penelitian Kehutanan Wallacea, 5(2), 103-111.

Siregar, C.A., \& Heriyanto, N.M. (2010). Akumulasi biomasa karbon pada skenario hutan sekunder di Maribaya, Bogor, Jawa Barat. Jurnal Penelitian Hutan dan Konservasi Alam, 8(3), 215-226.
R. Garsetiasih, Anita Rianti dan N.M. Heriyanto

Soerianegara, I., \& Indrawan, A. (2008). Ekologi Hutan Indonesia. Laboratorium Ekologi Hutan. Jurusan Manajemen Hutan, Fakultas Kehutanan (ID): Institut Pertanian Bogor.

Subiandono, E., Bismark, M., \& Heriyanto, N.M. (2013). Kemampuan Avicennia marina (Forsk.) Vierh. dan Rhizophora apiculata Bl. dalam penyerapan polutan logam berat. Jurnal Penelitian Hutan dan Konservasi Alam, 10(1), 35-44.

Suprihatno, B., Hamidy, R., \& Amin, B. (2012). Analisis biomassa dan cadangan karbon tanaman bambu balangke (Gigantochioa pruriens). Journal of Environmental Science, $6(1), 82-92$. 